\title{
Spatial changes in inclusion band spacing as an indicator of temporal changes in slow slip and tremor recurrence intervals
}

\author{
Naoki Nishiyama ${ }^{{ }^{*}}$ (D), Kohtaro Ujiie ${ }^{1}$ and Masayuki Kano ${ }^{2}$
}

\begin{abstract}
Slow slip and tremor (SST) downdip of the seismogenic zones may trigger megathrust earthquakes by frequently transferring stress to seismogenic zones. Geodetic observations have suggested that the recurrence intervals of slow slip decrease toward the next megathrust earthquake. However, temporal variations in the recurrence intervals of SST during megathrust earthquake cycles remain poorly understood because of the limited duration of geodetic and seismological monitoring of slow earthquakes. The quartz-filled, crack-seal shear veins in the subduction mélange deformed near the downdip limit of the seismogenic zone in warm-slab environments record cyclic changes in the inclusion band spacing in the range from $4 \pm 1$ to $65 \pm 18 \mu \mathrm{m}$. The two-phase primary fluid inclusions in quartz between inclusion bands exhibit varying vapor/liquid ratios regardless of inclusion band spacing, suggesting a common occurrence of fast quartz sealing due to a rapid decrease in quartz solubility associated with a large fluid pressure reduction. A kinetic model of quartz precipitation, considering a large fluid pressure change and inclusion band spacing, indicates that the sealing time during a single crack-seal event cyclically decreased and increased in the range from $0.16 \pm 0.04$ to $2.7 \pm 0.8$ years, with one cycle lasting at least $27 \pm 2$ to $93 \pm 5$ years. The ranges of sealing time and duration of a cycle may be comparable to the recurrence intervals of SST and megathrust earthquakes, respectively. We suggest that the spatial change in inclusion band spacing is a potential geological indicator of temporal changes in SST recurrence intervals, particularly when large fluid pressure reduction occurs by brittle fracturing.
\end{abstract}

Keywords: Crack-seal vein, Subduction mélange, Slow slip and tremor, Recurrence interval

\section{Main text Introduction}

Slow slip and tremor (SST) are characterized by transient plate boundary slip that lasts from days to years with recurrence intervals on the order of months to years (Behr and Bürgmann 2021). It has been suggested that repeated slow earthquakes such as SST may trigger megathrust earthquakes due to frequent stress loading on the adjacent locked seismogenic zone (Obara and Kato 2016; Voss et al. 2018). Numerical simulations have

\footnotetext{
*Correspondence: nnishiyama@geol.tsukuba.ac.jp

${ }^{1}$ Faculty of Life and Environmental Sciences, University of Tsukuba, 1-1-1

Tennodai, Tsukuba 305-8572, Japan

Full list of author information is available at the end of the article
}

established that recurrence intervals of short-term slow slip events (S-SSEs) temporally decreased from 0.6-2 to $0.2-0.6$ years towards a next megathrust earthquake, whereas those after the megathrust earthquake increased to $0.6-2$ years due to stress perturbations from the megathrust rupture (Matsuzawa et al. 2010; Mitsui 2015; Luo and Liu 2019). A recent geodetic study in the Nankai subduction zone revealed that the recurrence interval of S-SSEs from 1969 to 2012 may have decreased from $>5$ years to $\sim 1$ year (Kano and Kano 2019). However, the temporal variations in the recurrence intervals of SST during megathrust earthquake cycles remain poorly understood because of the limited duration of seismological and geodetic observations of SST.

\section{Springer Open}

(c) The Author(s) 2021. This article is licensed under a Creative Commons Attribution 4.0 International License, which permits use, sharing, adaptation, distribution and reproduction in any medium or format, as long as you give appropriate credit to the original author(s) and the source, provide a link to the Creative Commons licence, and indicate if changes were made. The images or other third party material in this article are included in the article's Creative Commons licence, unless indicated otherwise in a credit line to the material. If material is not included in the article's Creative Commons licence and your intended use is not permitted by statutory regulation or exceeds the permitted use, you will need to obtain permission directly from the copyright holder. To view a copy of this licence, visit http://creativeco mmons.org/licenses/by/4.0/. 
Geophysical studies in the Cascadia subduction zone have suggested that the recurrence interval of episodic tremor and slip (ETS) may be controlled by silica precipitation in the upper plate (Audet and Bürgmann 2014; Hyndman et al. 2015). Geological studies of subduction mélanges deformed at the frictional-viscous transition downdip of the thermally controlled seismogenic zone suggest that the quartz-filled crack-seal shear veins may represent the generation of repeated tremors, including low-frequency earthquakes (LFEs), that occurred nearlithostatic fluid overpressures with a low stress drop of approximately a few tens of $\mathrm{kPa}$ (Fagereng et al. 2011; Ujiie et al. 2018). In the Makimine mélange of the Late Cretaceous Shimanto accretionary complex of eastern Kyushu, Japan (Fig. 1a, b), the crack-seal shear veins recorded repeated low-angle brittle thrusting with a minimum time interval between thrusting events of less than a few years (Ujiie et al. 2018), which may be comparable to the recurrence intervals of SST. A similar time interval between crack-seal events was also reported for the quartz-filled extension veins in the Kodiak accretionary complex, southwest Alaska (Fisher and Brantley 2014). Thus, crack-seal veins appear to provide clues for understanding temporal changes in the SST recurrence intervals. In this study, we examined crack-seal shear veins in the Makimine mélange. First, we show spatial changes in the inclusion band spacing and evidence of large fluid pressure reductions during crack-seal events. We then discuss the implications for temporal changes in the recurrence intervals of SST.

\section{Occurrence of crack-seal veins in the Makimine mélange}

The Makimine mélange underwent prehnite-actinolite to greenschist facies metamorphism at $\sim 300-350{ }^{\circ} \mathrm{C}$ and 10-15 km depth (Toriumi and Teruya 1988; Hara and Kimura 2008; Palazzin et al. 2016), comparable to the conditions near the downdip limit of the thermally controlled seismogenic zone in warm-slab environments (Hyndman et al. 1997). The geological structure of the Makimine mélange along the seacoast is characterized by the repetition of mudstone-dominated mélange containing metabasalt lenses, reddish brown tuff, and sandstone-mudstone mélange with bedded sandstone and mudstone, which has been interpreted to result from the duplex underplating of the subduction mélange in which the ocean plate stratigraphy is preserved (Ujiie et al. 2018) (Fig. 1b).

Quartz-filled shear veins, foliation-parallel extension veins, and subvertical extension veins constitute $\sim 10-60 \mathrm{~m}$ thick vein concentration zones in the structurally lower part of the mélange (Fig. 1). The vein concentration zones are laterally continuous

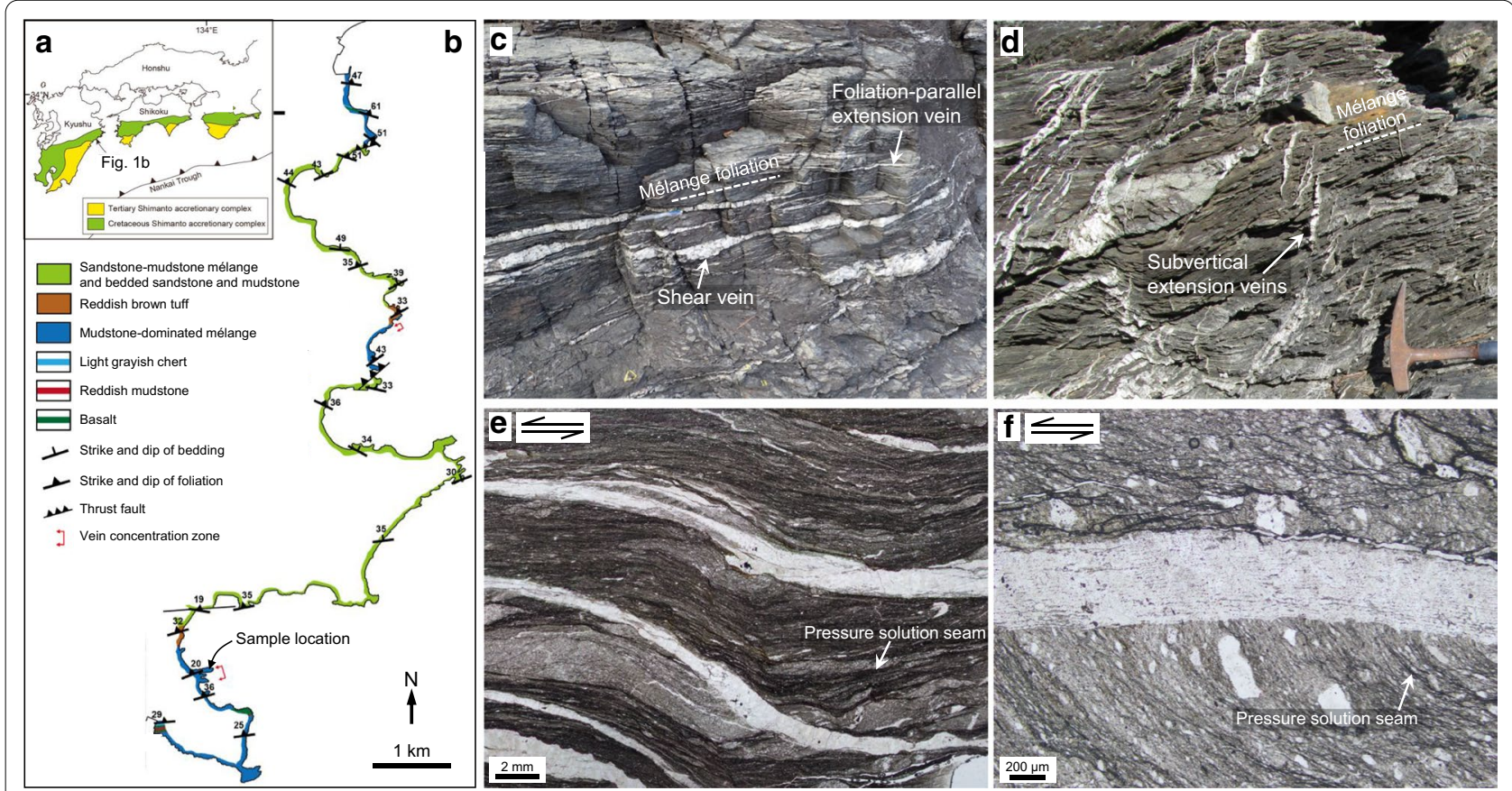

Fig. 1 a Distribution of the Shimanto accretionary complex in southwest Japan. b Geological map of the Makimine mélange along the east coast of Kyushu Island ( modified from Ujiie et al. 2018). Location of the map is shown in Fig. 1a. c Occurrence of shear veins and foliation-parallel veins in the Makimine mélange. $\mathbf{d}$ Subvertical extension veins showing en echelon arrays. e Micrograph of the viscously deformed veins. $\mathbf{f}$ Crack seal, subhorizontal extension vein cutting viscous fabrics formed by pressure solution creep. e, f Plane-polarized light 
for $>100 \mathrm{~m}$ along the strike. Shear veins are subparallel to the foliation-parallel extension veins (Fig. 1c). The occurrence of shear veins and foliation-parallel extension veins could represent the development of faultfracture meshes in the subhorizontal mélange shear zone deformed at very low angles to the greatest principal compressive stress $\left(\sigma_{1}\right)$ and nearly perpendicular to the least principal compressive stress which is approximately equal to the vertical stress. Thus, shear veins are considered to develop under near-lithostatic fluid overpressures. A noble gas analysis of the shear veins suggests that the infiltration of fluid derived from the serpentinized mantle may contribute to the generation of elevated fluid pressures (Nishiyama et al. 2020). The quartz slickenfibers on the surfaces of the shear veins indicate a top-SSE shear, consistent with the megathrust shear during the Late Cretaceous (cf. Ujiie et al. 2018). Subvertical extension veins commonly display en echelon arrays at high angles to the foliation (Fig. 1d). This suggests that the orientation of $\sigma_{1}$ transiently changed to vertical, which is also indicative of nearlithostatic fluid overpressures. The vein concentration zones include the viscous shear zones with thicknesses of $<10 \mathrm{~m}$. Within the viscous shear zones, the shear veins and foliation-parallel extension veins are sigmoidally or asymmetrically deformed, while these veins cut viscous fabrics formed by pressure solution creep (Fig. 1e, f). These features suggest the contemporaneous occurrence of brittle fracturing and viscous shear.

Shear veins commonly exhibit crack-seal texture defined by the alignment of phyllosilicate inclusion bands (Fig. 2 and Additional file 1: Figure S1). The inclusion bands are subparallel to the vein margin, indicating the opening of the shear vein at a high angle to the vein margin (Fig. 2). The opening direction of shear veins, as well as their orientation at very low angles to $\sigma_{1}$, indicates that shear veins in the Makimine mélange occur as dilational shear fractures. In places, the elongate-blocky quartz crystal is recognized oblique to the vein margin, with the quartz grain sizes increasing upward from the lower vein margin (Fig. 2d). The unitaxial growth of quartz and the geometry of the dilational stepovers with respect to the shear direction indicate that the oldest part of the fibers lies along the lower margin of the vein. Thus, spatial variations in the inclusion band spacing within the shear vein suggest temporal changes in the inclusion band spacing (Figs. 2a-c). Slip increment, estimated from fiber growth increments at dilational stepover, was 0.1$0.2 \mathrm{~mm}$ (Ujiie et al. 2018). Microstructures related to dynamic recrystallization, such as bulging and subgrain rotation recrystallization structures (Stipp et al. 2002), are absent in the shear veins.
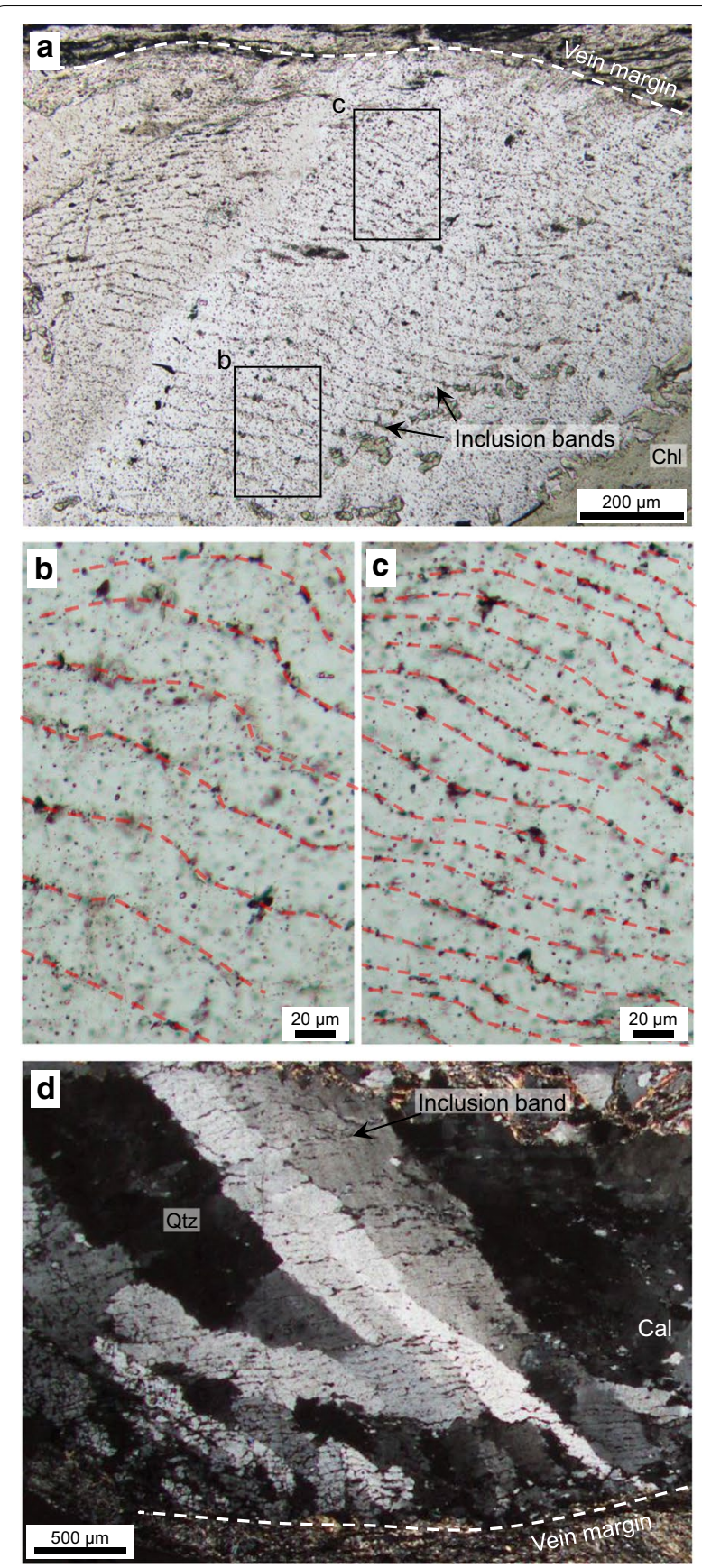

Fig. 2 a Micrograph (plane-polarized light) of phyllosilicate inclusion bands (transect 3 in sample R2) showing upward decrease in band spacing. $\mathbf{b}, \mathbf{c}$ Closeup of inclusion bands. Locations of the images are shown in (a). Dashed red lines indicate inclusion bands. $\mathbf{d}$ Micrograph (cross-polarized light) of shear vein, showing an elongate-blocky quartz crystals. All micrographs were taken from the thin sections cut parallel to slickenfiber lineations and perpendicular to vein margin. $\mathrm{Qtz}=$ quartz, Chl $=$ chlorite 


\section{Results}

\section{Spatial changes in inclusion band spacing}

To examine the spatial changes in the inclusion band spacing, we used two shear veins (samples R1 and R2) and made the thin sections cut parallel to the slickenfiber lineations and perpendicular to the vein margin. As the inclusion bands were locally discontinuous along their length, we set several transects for each shear vein and numbered them sequentially from the lower margin of the vein (Additional file 1: Figure S2). The distance between the transects ranged from 0.1 to $3.5 \mathrm{~mm}$. The measurement of the inclusion band spacing was conducted using digital photomicrographs taken by an optical microscope with magnifications of $10 \times$ and $20 \times$. The individual band spacings were calculated by averaging the measurement values for 3-10 points. The number of inclusion bands in the transects ranged from 22 to 77 (Additional file 1: Table S1). Each shear vein records a minimum of 120 crack-seal events (Additional file 1: Table S1).

Both shear veins record spatial changes in inclusion band spacing, with minimum and maximum values of $4 \pm 1$ and $65 \pm 18 \mu \mathrm{m}$, respectively (Fig. 3). Sample R2 shows a spatial decrease and increase in the inclusion band spacing (Figs. 3a-d). Similar features were observed in sample R1, although the data are more scattered than those of sample R2 (Fig. 3e, f). At least, two cycles of spatial change were observed in the inclusion band spacing for both samples.

\section{Fluid pressure change during crack-seal events}

Two-phase primary fluid inclusions were commonly observed in the quartz between the inclusion bands, showing various vapor/liquid ratios (Fig. 4). The homogenization temperature during a single crack-seal event was difficult to measure as the spacing of inclusion bands was too thin to measure using a heating and cooling stage mounted on a microscope. To evaluate the fluid pressure change during a single crack-seal event, we measured the volume fraction of vapor $\left(V_{\mathrm{v}}\right)$ in the primary fluid inclusion between adjacent inclusion bands using micrographs (Fig. 4), and then determined the volume fraction of liquid water $\left(V_{\mathrm{r}}\right)$ by subtracting $V_{\mathrm{v}}$ from 1 . In the measurements, we avoided measuring secondary inclusions along the healed cracks and the fluid inclusions that suffered from post-entrapment necking. Re-equilibration of fluid inclusions by stretching (Goldsten and Raynolds 1994; Ujiie et al. 2008) or dynamic recrystallization (Kerrich 1976) is unlikely as stretching of fluid inclusions in quartz commonly occurs at temperatures above $370{ }^{\circ} \mathrm{C}$ (Bodnar et al. 1989), which is higher than the maximum temperature of the coastal Makimine mélange $\left(\sim 330^{\circ} \mathrm{C}\right.$,
Ujiie et al. 2018). In addition, microstructural observations indicate the absence of dynamic recrystallization in shear veins. Assuming a constant water mass in the fluid inclusion, the water density at the homogenization temperature $\left(\rho_{\mathrm{h}}\right)$ was estimated as

$$
\rho_{\mathrm{h}}=\rho_{\mathrm{r}} \frac{V_{\mathrm{r}}}{V}
$$

where $\rho_{\mathrm{r}}$ is the water density at room temperature $\left(1 \mathrm{~g} \mathrm{~cm}^{-3}\right)$, and $V$ is the volume fraction of liquid water at the homogenization temperature (i.e., $V=1$ ). The fluid pressure was calculated from the isochore of $\rho_{\mathrm{h}}$, which was obtained using LonerHGK (http://fluids.unileoben. ac.at).

The $V_{\mathrm{r}} / V$ values of the fluid inclusions trapped in a single crack-seal event ranged from 63 to $91 \%$ (Fig. 4f-i). The range of $V_{\mathrm{r}} / V$ values did not correlate with the inclusion band spacing, which ranged from 9 to $51 \mu \mathrm{m}$ (Fig. $4 \mathrm{f}-\mathrm{i}$ ). Assuming that the fluid temperature corresponds to the maximum temperature of the coastal Makimine mélange $\left(330{ }^{\circ} \mathrm{C}\right)$, the fluid pressure changes, determined from isochores of the minimum and maximum values of $\rho_{\mathrm{h}}$, ranged from 222 to $280 \mathrm{MPa}$ (Figs. $4 \mathrm{j}-\mathrm{m}$ ), which is comparable to the fluid pressure drop from lithostatic to hydrostatic values at a depth of $15 \mathrm{~km}$ (235 MPa using a rock density of $2.6 \mathrm{~g} \mathrm{~cm}^{-3}$ ).

\section{Discussion}

\section{Temporal changes in sealing time}

Fluid inclusion analysis revealed a large fluid pressure change during each crack-seal event (Fig. 4). This may also be indicated by the wide variation in the homogenization temperatures $\left(150-280{ }^{\circ} \mathrm{C}\right.$ ) across multiple solid inclusion bands in the shear veins from the same vein concentration zone in the Makimine mélange (Nishiyama et al. 2020). To estimate the time for each crack-seal event, we considered fluid advection through the cracked shear vein, during which fluid pressure dropped from lithostatic to hydrostatic (235 MPa at a depth of $15 \mathrm{~km}$ ). The kinetic equation of quartz precipitation driven by a fluid pressure drop in an advecting fluid is given as (Rimstidt and Barnes 1980):

$$
\frac{\partial C_{\mathrm{SiO}_{2}}}{\partial t}=k \frac{A_{\mathrm{H}_{2} \mathrm{O}}}{M_{\mathrm{H}_{2} \mathrm{O}}}\left(C_{\mathrm{SiO}_{2}, \mathrm{eq}}-C_{\mathrm{SiO}_{2}}\right)
$$

where $C_{\mathrm{SiO} 2}$ is the concentration of $\mathrm{SiO}_{2}$ in the fluid, $C_{\mathrm{SiO} \text {,eq }}$ is the solubility of quartz in the fluid at hydrostatic pressure, $t$ is the time, $M_{\mathrm{H} 2 \mathrm{O}}$ is the mass of $\mathrm{H}_{2} \mathrm{O}$ in the crack, and $A_{\mathrm{H} 2 \mathrm{O}}$ is the reactive surface area. $k$ is the precipitation rate of quartz, which is empirically determined by $\log _{10} k=-0.0886-2638 / T$, where $T$ is the temperature (Okamoto et al. 2010). Following Ujiie et al. 


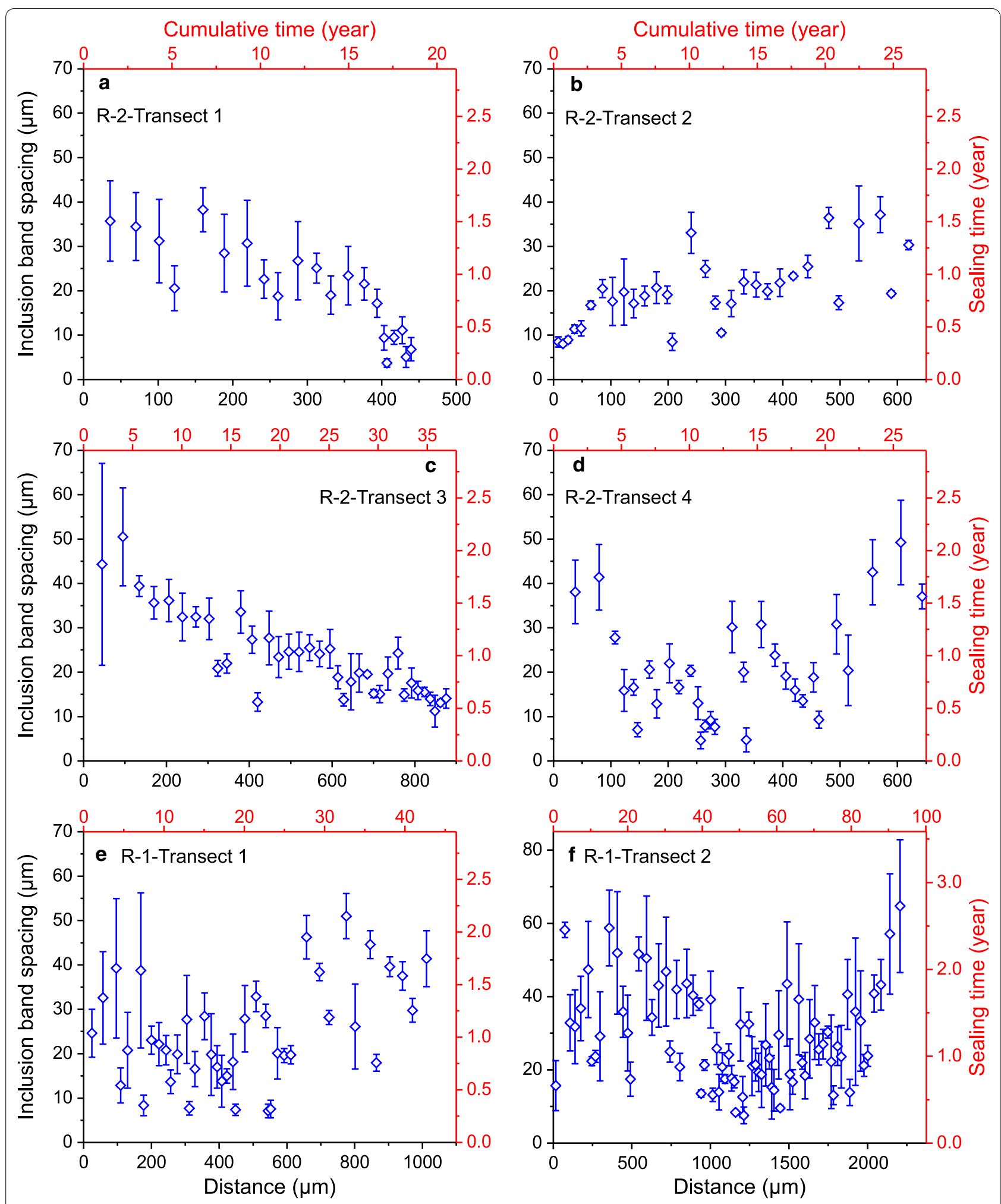

Fig. 3 Spatial changes in the inclusion band spacing for transects 1-4 in sample R2 (a-d) and for transects 1-2 in sample R1 (e, f). Right and upper axes (red) represent the sealing time between crack-seal events as a function of cumulative time 


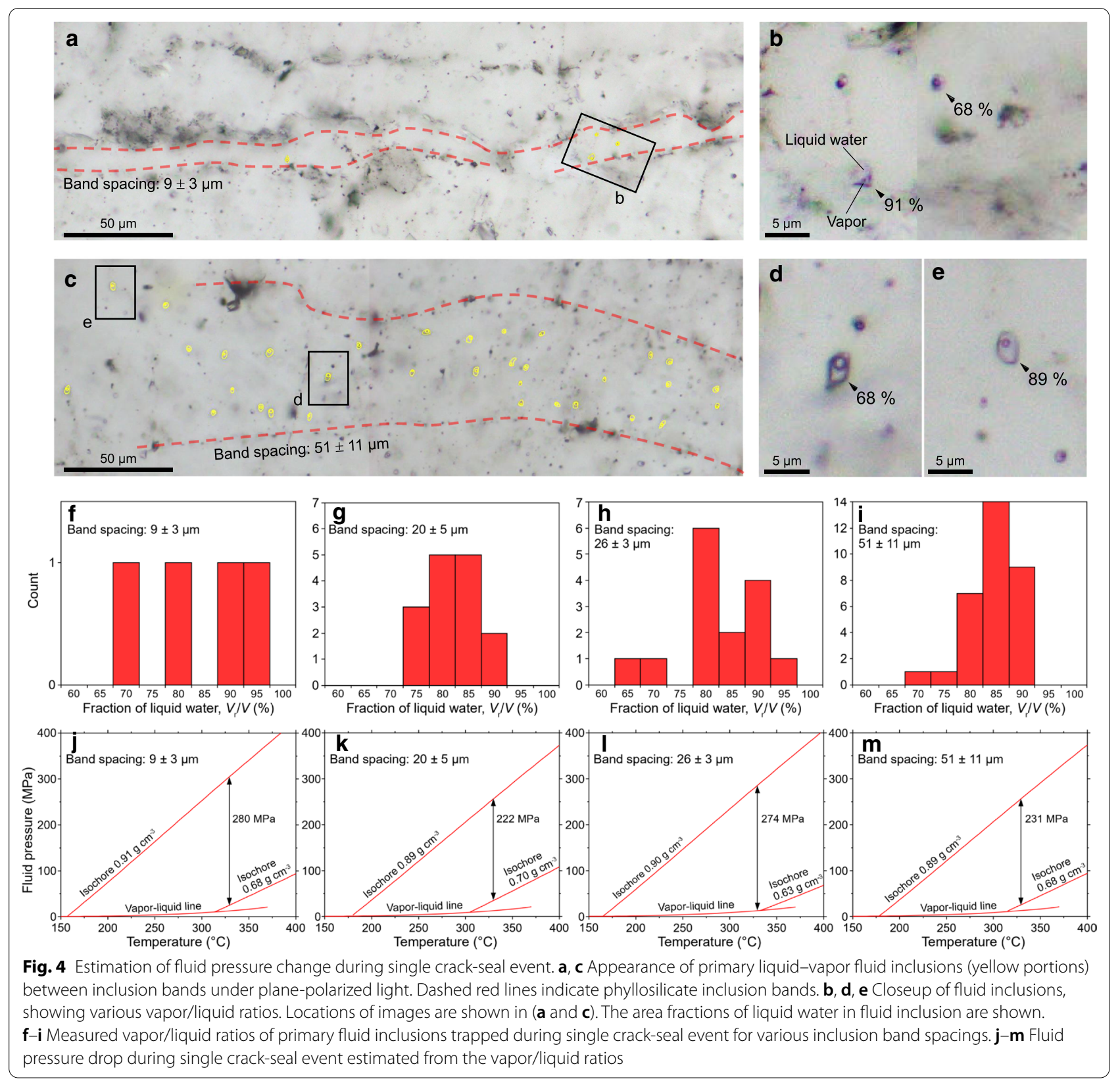

(2018), the model considered inclusion band spacing, a typical length of shear veins $(1 \mathrm{~m})$, a temperature of $330{ }^{\circ} \mathrm{C}$, and fluid pressure drop from lithostatic to hydrostatic values. We assumed that the precipitation rate of quartz remained constant regardless of the band spacing. The $\mathrm{SiO}_{2}$ concentration at $t=0$ was equal to the quartz solubility at lithostatic fluid pressure and dropped to $C_{\mathrm{SiO} 2 \text {,eq }}+0.001 \mathrm{mg} \mathrm{kg}^{-1}$ through the crack. Quartz solubility was calculated using LonerAP, developed by Akinfiev and Diamond (2009).
Figure 3 shows the temporal changes in sealing time between individual thrusting events. The sealing time cyclically changed between $0.16 \pm 0.04$ and $2.7 \pm 0.8$ years, with a mean value of 1.1 years. Based on the results, we estimated the durations of the decrease and increase in the sealing time. In the estimations for transect 4 of sample R2 and transects 1 and 2 of sample R1, we assumed that the decrease in sealing time continued until the sealing time reached its minimum value (Figs. $3 \mathrm{~d}-\mathrm{f}$ ). The estimated durations of temporal 
decrease and increase in the sealing time ranged from $11 \pm 1$ to $51 \pm 2$ years and from $16 \pm 1$ to $42 \pm 3$ years, respectively.

\section{Relating temporal changes in sealing time to SST recurrence intervals}

Assuming complete crack healing during crack-sealing by fluid advection, the estimated sealing time of $\sim 0.16-$ 2.7 years between each crack-seal event gives the minimum time interval of repeated brittle fracturing events. Crack-seal events can also occur through the local transport of silica by diffusion (Renard et al. 2000; Fisher and Brantley 2014). Fisher et al. (2019) considered that the diffusive distribution of silica in mélange shear zones was promoted by a transient drop in fluid pressure or a difference in mean stress between blocks and matrix in the mélange. The latter is unlikely for the shear veins in the Makimine mélange as the vein concentration zone is poor in blocks, while shear veins mostly developed in the mudstone matrix (Fig. 1c). When crack-seal events take place by local diffusion of silica driven by the fluid pressure difference between the wall rock and crack, the sealing time $(t)$ can be expressed as (Fisher and Brantley 2014)

$$
t=\frac{k_{d} l^{2}+2 V_{q} \phi \tau D_{f} F_{d} C_{2} l}{2 k_{d} l V_{q} \phi \tau D_{f} F_{d}\left(C_{\mathrm{SiO}_{2}, 1}-C_{\mathrm{SiO}_{2}, 2}\right)}
$$

where $k_{d}$ is the dissolution rate constant of quartz, $l$ is the inclusion band spacing, $V_{\mathrm{q}}$ is the molar volume of quartz, $\phi$ is the porosity of the wall rock, $\tau$ is the tortuosity, $D_{\mathrm{f}}$ is the diffusion coefficient of silica through the grain boundary, $C_{\mathrm{SiO}_{2}, 1}$ and $C_{\mathrm{SiO}_{2}, 2}$ are the quartz solubility at the site of dissolution (wall rock) and growth (crack), respectively, and $F_{\mathrm{d}}$ is the volume fraction of dissolved quartz in the wall rock. $k_{d}$ was obtained from the kinetic equation proposed by Tester et al. (1994). $\phi$ was assumed to be 0.01 , based on the porosities of metasediments metamorphosed at depths of 10-15 km (Bray and Karig 1985). $D_{\mathrm{f}}$ and $\tau$ were $1 \times 10^{-10} \mathrm{~m}^{2} \mathrm{~s}^{-1}$ and 1 , respectively (Fisher and Brantley 1992; Gratier et al. 2009). The $F_{\mathrm{d}}$ value of 0.11 was obtained from the difference in $\mathrm{SiO}_{2}$ concentration between mudstone in the vicinity of the shear vein and mudstone far from the vein. $\mathrm{SiO}_{2}$ concentrations were estimated from the results of inductively coupled plasma mass spectrometry measurements. $C_{\mathrm{SiO}_{2}, 1}$ and $C_{\mathrm{SiO}_{2}, 2}$ were calculated using the LonerAP software. Figure $5 \mathrm{a}$ shows the relationship between the fluid pressure difference and the sealing time estimated from Eq. (3). When the fluid pressure changes from lithostatic to hydrostatic values at the depth of $15 \mathrm{~km}$, the sealing time ranged from $0.04 \pm 0.02$ to $4 \pm 2$ years, comparable to the time of crack-sealing by fluid advection (Fig. 5). Thus, irrespective of whether the crack sealing occurred by fluid advection or local diffusion, the minimum time interval of individual brittle thrusting was in the range of 0.04-4 years when the fluid pressure changed from lithostatic to hydrostatic values. Considering the infiltration of mantle-derived fluids into the Makimine mélange (Nishiyama et al. 2020) and the faultfracture mesh geometry in the vein concentration zone, rapid sealing by fluid advection rather than local diffusion of silica is likely to be the dominant mechanism of crack sealing.

The spacing of crack-seal bands may also reflect the local stress field or rock physical properties, as the crack aperture $(d)$ is expressed as $d \approx 2 \sigma L / E$, where $\sigma$ is the driving stress, $L$ is the crack length, and $E$ is the Young's
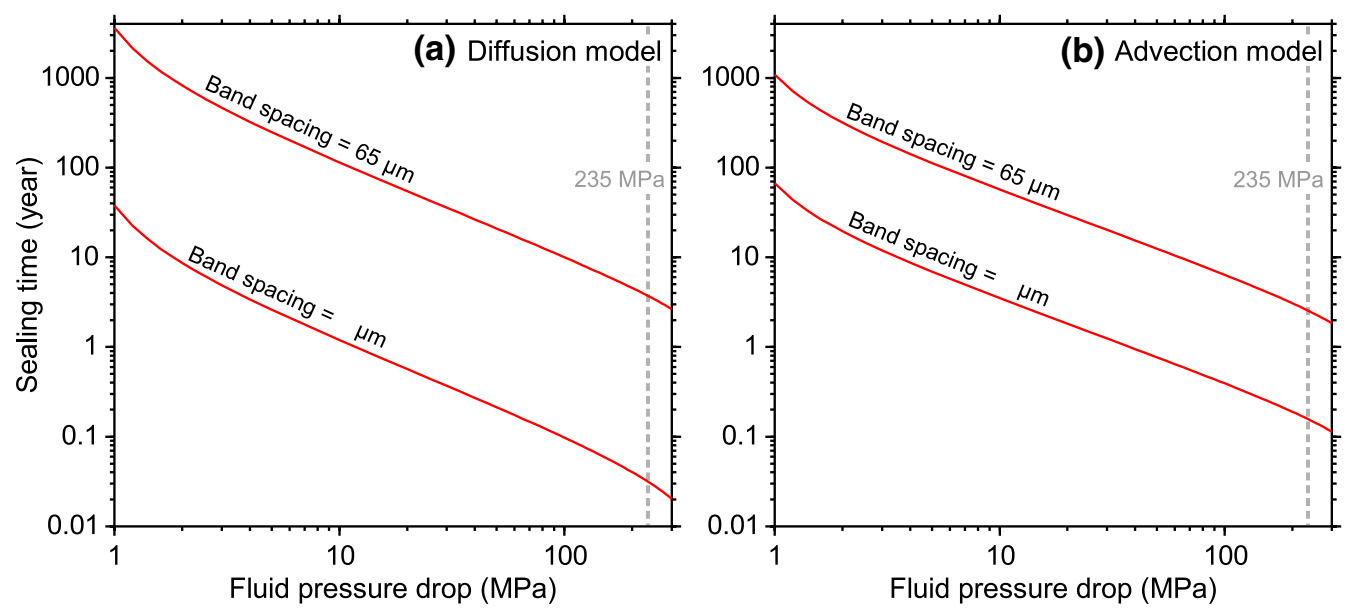

Fig. 5 Relationship between fluid pressure drop and time for crack-sealing by local diffusion (a) and by fluid advection (b). Vertical dotted lines represent the fluid pressure drop from lithostatic to hydrostatic values at a depth of $15 \mathrm{~km}$ 
modulus of the wall rock (Renard et al. 2005; Gudmundsson 2011; Fisher et al. 2019). Fisher et al. (1995) suggested that $E$ might progressively increase with an increase in quartz content due to vein growth, leading to a decrease in $d$. However, this is unlikely for the shear veins in the Makimine mélange as the band spacing not only decreased but also increased with time (Fig. 3). Alternatively, if $E$ and $L$ remain constant, the spatial change in the band spacing might reflect the temporal variation in $\sigma$ (Renard et al. 2005). Assuming $E=10-70 \mathrm{GPa}$ for mudstones (Turcotte and Schubert 2002), $d=4-65 \mu \mathrm{m}$, and $L=1 \mathrm{~m}$, the spatial changes in band spacing may reflect temporal variations in $\sigma$ in the range of 0.31-2.1 MPa. These small values of $\sigma$ are consistent with the inferred elevated fluid pressure in the vein concentration zones in the Makimine mélange.

The kinematics of low-angle thrust faulting, 0.1$0.2 \mathrm{~mm}$ slip increments, and brittle fracturing under near-lithostatic fluid pressures recorded in the shear veins may be comparable to conditions of LFEs (Shelly et al. 2006, 2007; Bostock et al. 2012, 2015). However, the length of individual shear veins is $\sim 1-10 \mathrm{~m}$, which is smaller than the dimensions of individual LFEs, ranging from 100 to $1000 \mathrm{~m}$ (Bostock et al. 2015). On the other hand, the length scales of the vein concentration zones are $>100 \mathrm{~m}$, similar to those of the LFEs. The estimated sealing time of $\sim 0.16-2.7$ years is longer than the recurrence interval of LFEs (seconds to days, Frank et al. 2015) but is comparable to that of the SST (months to years, Behr and Bürgmann 2021). Considering that the shear veins constitute fault-fracture meshes in the subducting mélange, brittle fracturing at individual shear veins may represent a small component of tremor composed of LFEs, which occurred in different locations within the $\sim 10-60 \mathrm{~m}$ thick vein concentration zones.

The lithostatic to hydrostatic pressure changes (222$280 \mathrm{MPa}$ ) recorded in the crack-seal shear veins appear to be much larger than the small stress drop (1-100 kPa) and the small fluid pressure change (1-10 $\mathrm{MPa}$ ) observed in the SST source area (Rubinstein et al. 2007; Bostock et al. 2015; Gosselin et al. 2020). The stress drop can be large when the shear strength $(\tau)$ is described by the effective normal stress, $\tau=C+\mu\left(\sigma_{\mathrm{n}}-P_{\mathrm{f}}\right)$, where $C$ is the cohesive strength, $\mu$ is the friction coefficient, $\sigma_{\mathrm{n}}$ is the normal stress, and $P_{\mathrm{f}}$ is the fluid pressure. However, the shear veins in the Makimine mélange formed as dilational shear fractures, as indicated by the shear veins at a very small angle $\left(5.5^{\circ}\right)$ to $\sigma_{1}$ and the opening of shear veins at high angles to the vein margin (Ujiie et al. 2018 and Fig. 2). In this case, $\tau$ can be written as $\tau^{2}-4 T_{0} \sigma_{\mathrm{n}}-4 T_{0}^{2}=0$, where $T_{0}$ is the tensile strength. Therefore, the stress drop may remain very small even if fluid pressure changes were large. Indeed, the stress drop, estimated from slip increments $(0.1-0.2 \mathrm{~mm})$, vein length (1-10 m), and shear modulus (3 GPa, Takahashi et al. 2002), was in the order of tens to hundreds of $\mathrm{kPa}$, which is consistent with the estimated small stress drops during SST (cf. Fagereng et al. 2011; Ujiie et al. 2018).

Large discrepancies in fluid pressure changes between geophysical and geological observations may arise from the large differences in spatial resolution. While large fluid pressure changes were derived from the fluid inclusions between volumetrically minor crack-seal bands of several tens of microns in thickness, small fluid pressure changes were estimated from receiver function data at vertical scale lengths of $1-10 \mathrm{~km}$, which could represent averaged fluid pressure changes in the low-velocity layer (LVL) (Gosselin et al. 2020). Thus, while large fluid pressure changes could occur in narrow cracks, the entire fluid pressure changes in the subduction mélange (or LVL) may be small.

The analyzed shear veins recorded two cycles of temporal decrease and increase in sealing time, with one cycle lasting $\geq 27 \pm 2$ to $93 \pm 5$ years. The range of one cycle duration is within the recurrence intervals of megathrust earthquakes larger than $M_{\mathrm{w}} 7$ in subduction zones. Historical documents, historical earthquakes, and geological records of tectonic subsidence and tsunami over the last $\leq 8000$ years indicate that the recurrence intervals of megathrust earthquakes in the Nankai, Sumatra, and Chile subduction zones were 90-200, 63-157, and 128-300 years, respectively (Additional file 1: Table S2; Lomnitz 1970; Ando 1975; Bilham et al. 2005; Cisternas et al. 2005; Malik et al. 2019). Therefore, if the inclusion band spacing in the analyzed shear veins represents the SST recurrence interval, our results suggest that the SST recurrence interval may temporally decrease and increase during megathrust earthquake cycles.

\section{Conclusions}

The crack-seal shear veins in the Makimine mélange deformed near the downdip limit of the seismogenic zone in the warm subduction zone recorded cyclic changes in the inclusion band spacing. The vapor/liquid ratios of primary fluid inclusions between adjacent inclusion bands suggest the common occurrence of a large fluid pressure drop during crack-seal events. When fast quartz sealing occurred due to a decrease in quartz solubility associated with a large fluid pressure reduction, the sealing time between crack-seal events is comparable to the recurrence intervals of SST. We suggest that the cyclic changes in the band spacing could represent the temporal change in the recurrence intervals of SST during megathrust earthquake cycles. 


\section{Abbreviations}

SST: Slow slip and tremor; S-SSEs: Short-term slow slip events; LFEs: Lowfrequency earthquakes; ETS: Episodic tremor and slip; LVL: Low-velocity layer.

\section{Supplementary Information}

The online version contains supplementary material available at https://doi. org/10.1186/s40623-021-01448-7.

Additional file 1: Table S1. Characteristics of inclusion band spacing in shear veins. Table S2. Recurrence intervals of megathrust earthquakes for subduction zones. Figure S1. Photomicrograph of phyllosilicate inclusion bands in each transect in samples R2 (a-c) and R1 (d, e). Figure S2. Photographs of thin sections from sample R2 and R1, showing the locations of transects.

\section{Acknowledgements}

The manuscript has been greatly improved by the comments of the Editor Pascal Audet, Whitney Behr, and an anonymous reviewer. We thank Donald Fisher for reviewing an earlier version of this paper. We thank T. Ishikawa and T. Kawai for technical assistance in chemical analyses using inductively coupled plasma mass spectrometer at Kochi Institute for Core Sample Research.

\section{Authors' contributions}

NN, MK and KU designed this study. NN carried out measurements. NN and $\mathrm{KU}$ performed calculations. NN and KU conducted field observations and sampling. NN prepared the manuscript and KU and MK revised the manuscript. All authors discussed the results. All authors read and approved the final manuscript.

\section{Funding}

This research was supported by the Japan Society for the Promotion of Science KAKENHI Grant JP16H06476, 20KK0078, 19H04620 and 17H05319.

\section{Availability of data and materials}

The data presented in this study are available by contacting the corresponding author.

\section{Declarations}

Ethics approval and consent to participate

Not applicable.

\section{Consent for publication}

Not applicable.

\section{Competing interests}

The authors declare that they have no competing interests.

\section{Author details}

${ }^{1}$ Faculty of Life and Environmental Sciences, University of Tsukuba, 1-1-1 Tennodai, Tsukuba 305-8572, Japan. ${ }^{2}$ Graduate School of Science, Tohoku University, 6-3, Aramaki-aza-aoba, Aoba-ku, Sendai 980-8578, Japan.

Received: 15 March 2021 Accepted: 1 June 2021

Published online: 10 June 2021

\section{References}

Akinfiev NN, Diamond LW (2009) A simple predictive model of quartz solubility in water-salt-CO2 systems at temperatures up to $1000^{\circ} \mathrm{C}$ and pressures up to $1000 \mathrm{MPa}$. Geochim Cosmochim Acta 73:1597-1608. https://doi. org/10.1016/j.gca.2008.12.011

Ando M (1975) Source mechanisms and tectonic significance of historical earthquakes along the Nankai Trough, Japan. Tectonophysics 27:119-140. https://doi.org/10.1016/0040-1951(75)90102-X
Audet P, Bürgmann R (2014) Possible control of subduction zone slow-earthquake periodicity by silica enrichment. Nature 510:389-392. https://doi. org/10.1038/nature13391

Behr WM, Bürgmann R (2021) What's down there? The structures, materials and environment of deep-seated slow slip and tremor. Phil Trans R Soc A 379:20200218. https://doi.org/10.1098/rsta.2020.0218

Bilham R, Engdahl ER, Feldl N, Satyabala SP (2005) Partial and complete rupture of the Indo-Andaman plate boundary 1847-2004. Seismol Res Lett 76:299-311. https://doi.org/10.1785/gssrl.76.3.299

Bodnar RJ, Binns PR, Hall DL (1989) Synthetic fluid inclusions-VI. Quantitative evaluation of the decrepitation behavior of fluid inclusions in quartz at one atmosphere confining pressure. J Metamorphic Geol 7:229-242. https://doi.org/10.1111/j.1525-1314.1989.tb00586.x

Bostock MG, Royer AA, Hearn EH, Peacock SM (2012) Low frequency earthquakes below southern Vancouver Island. Geochem Geophys Geosyst 13:Q11007. https://doi.org/10.1029/2012GC004391

Bostock MG, Thomas AM, Savard G, Chuang L, Rubin AM (2015) Magnitudes and moment-duration scaling of low-frequency earthquakes beneath southern Vancouver Island. J Geophys Res Solid Earth 120:6329-6350. https://doi.org/10.1002/2015JB012195

Bray CJ, Karig DE (1985) Porosity of sediments in accretionary prisms and some implications for dewatering processes. J Geophys Res 90:768-778. https://doi.org/10.1029/JB090iB01 p00768

Cisternas M, Atwater BF, Torrejón F, Sawai Y, Machuca G, Lagos M, Eipert A, Youlton C, Salgado I, Kamataki T, Shishikura M, Rajendran CP, Malik JK, Rizal Y, Husni M (2005) Predecessors of the giant 1960 Chile earthquake. Nature 437:404-407. https://doi.org/10.1038/nature03943

Fagereng $\AA$, Remitti F, Sibson RH (2011) Incrementally developed slickenfibers-geological record of repeating low stress-drop seismic events? Tectonophysics 510:381-386. https://doi.org/10.1016/j.tecto.2011.08.015

Fisher DM, Brantley SL (1992) Models of quartz overgrowth and vein formation: deformation and episodic fluid flow in an ancient subduction zone. J Geophys Res Solid Earth 97:20043-20061. https://doi.org/10.1029/ 92JB01582

Fisher DM, Brantley SM, Everett M, Dzvonik J (1995) Cyclic fluid flow through a regionally extensive fracture network within the Kodiak accretionary prism. J Geophys Res Solid Earth 100:12881-12894. https://doi.org/10. 1029/94JB02816

Fisher DM, Brantley SM (2014) The role of silica redistribution in the evolution of slip instabilities along subduction interfaces: constraints from the Kodiak accretionary complex, Alaska. J Struct Geol 69:395-414. https:// doi.org/10.1016/j.jsg.2014.03.010

Fisher DM, Smye AJ, Marone C, van Keken PE, Yamaguchi A (2019) Kinetic models for healing of the subduction interface based on observations of ancient accretionary complexes. Geochem Geophys Geosyst 20:34313449. https://doi.org/10.1029/2019GC008256

Frank WB, Radiguet FM, Rousset B, Shapiro NM, Husker AL, Kostoglodov V, Cotte N, Campillo M (2015) Uncovering the geodetic signature of silent slip through repeating earthquakes. Geophys Res Lett 42:2774-2779. https://doi.org/10.1002/2015GL063685

Goldsten RH, Reynolds TJ (1994) Systematics of fluid inclusions in diagenetic minerals. SEPM (Society for Sedimentary Geology) Short Course 31, Oklahoma.

Gosselin JM, Audet P, Estève C, McLellan M, Mohser SG, Schaeffer AJ (2020) Seismic evidence for megathrust fault-valve behavior during episodic tremor and slip. Sci Adv 6:eaay5174. https://doi.org/10.1126/sciadv.aay51 74

Gratier JP, Guiguet R, Renard F, Jenatton L, Bernard D (2009) A pressure solution creep law for quartz from indentation experiments. J Geophys Res Solid Earth 114:B03403. https://doi.org/10.1029/2008JB005652

Gudmundsson A (2011) Rock fractures in geological processes. Cambridge University Press, Cambridge

Hara H, Kimura K (2008) Metamorphic and cooling history of the Shimanto accretionary complex, Kyushu, Southwest Japan: implications for the timing of out-of-sequence thrusting. Isl Arc 17:546-559. https://doi.org/ 10.1111/j.1440-1738.2008.00636.x

Hyndman RD, Yamano M, Oleskevich DA (1997) The seismogenic zone of subduction thrust faults. Isl Arc 6:244-260. https://doi.org/10.1111/j.14401738.1997.tb00175.x

Hyndman RD, McCrory PA, Wech A, Kao H, Ague J (2015) Cascadia subducting plate fluids channelled to fore-arc mantle corner: ETS and silica 
deposition. J Geophys Res Solid Earth 120:4344-4358. https://doi.org/10. 1002/2015JB011920

Kano M, Kano Y (2019) Possible slow slip event beneath the Kii Peninsula, southwest Japan, inferred from historical tilt records in 1973. Earth Planets Space 71:95. https://doi.org/10.1186/s40623-019-1076-9

Kerrich R (1976) Some effects of tectonic recrystallisation on fluid inclusions in vein quartz. Contrib Mineral Petrol 59:195-202. https://doi.org/10.1007/ BF00371308

Lomnitz C (1970) Major earthquakes and tsunamis in Chile during the period 1535 to 1955. Geol Rundsch 59:938-960. https://doi.org/10.1007/BF020 42278

Luo Y, Liu Z (2019) Slow-slip recurrent pattern changes: perturbation responding and possible scenarios of precursor toward a megathrust earthquake. Geochem Geophys Geosyst 20:852-871. https://doi.org/10.1029/2018G C008021

Malik JN, Johnson FC, Khan A, Sahoo S, Irshad R, Paul D, Arora S, Baghel PK, Chopra S (2019) Tsunami records of the last 8000 years in the Andaman island, india, from mega and large earthquakes: insights on recurrence interval. Sci Rep 9:18463. https://doi.org/10.1038/s41598-019-54750-6

Matsuzawa T, Hirose H, Shibazaki B, Obara K (2010) Modeling short- and long- term slow slip events in the seismic cycles of large subduction earthquakes. J Geophys Res Solid Earth 115:B12301. https://doi.org/10. 1029/2010JB007566

Mitsui $Y$ (2015) Interval modulation of recurrent slow slip events by two types of earthquake loading. Earth Planets Space 67:56. https://doi.org/10. 1186/s40623-015-0230-2

Nishiyama N, Sumino H, Ujiie K (2020) Fluid overpressure in subduction plate boundary caused by mantle-derived fluids. Earth Planet Sci Lett 538:116199. https://doi.org/10.1016/j.epsl.2020.116199

Palazzin G, Raimbourg H, Famin V, Jolivet L, Kusaba Y, Yamaguchi A (2016) Deformation processes at the down-dip limit of the seismogenic zone: the example of Shimanto accretionary complex. Tectonophysics 687:28-43. https://doi.org/10.1016/j.tecto.2016.08.013

Obara K, Kato A (2016) Connecting slow earthquakes to huge earthquakes. Science 353:253-257. https://doi.org/10.1126/science.aaf1512

Okamoto A, Saishu H, Hirano N, Tsuchiya N (2010) Mineralogical and textural variation of silica minerals in hydrothermal flow-through experiments: implications for quartz vein formation. Geochim Cosmochim Acta 74:3692-3706. https://doi.org/10.1016/j.gca.2010.03.031

Renard F, Gratier JP, Jamtveit B (2000) Kinetics of crack-sealing, intergranular pressure solution, and compaction around active faults. J Struct Geol 22:1395-1407. https://doi.org/10.1016/S0191-8141(00)00064-X

Renard F, Andreani M, Bouillier AM, Labaume P (2005) Crack-seal patterns: Records of uncorrelated stress release variations in crustal rocks. In: Gapais D et al. (ed) Deformation Mechanisms, Rheology and Tectonics: From Minerals to the Lithosphere, vol 243. Geol Soc Spec Publ. pp 67-79
Rimstidt JD, Barnes HL (1980) The kinetics of silica-water reactions. Geochim Cosmochim Acta 44:1683-1699. https://doi.org/10.1016/0016-7037(80) 90220-3

Rubinstein JL, Vidale JE, Gomberg J, Bodin P, Creager KC, Malone SD (2007) Non-volcanic tremor driven by large transient shear stresses. Nature 448:579-582. https://doi.org/10.1038/nature06017

Shelly DR, Beroza GC, Ide S, Nakamura S (2006) Low-frequency earthquakes in Shikoku, Japan, and their relationship to episodic tremor and slip. Nature 442:188-191. https://doi.org/10.1038/nature04931

Shelly DR, Beroza GC, Ide S (2007) Non-volcanic tremor and low-frequency earthquake swarms. Nature 446:305-307. https://doi.org/10.1038/natur e05666

Stipp M, Stünitz H, Heilbronner R, Scmid SM (2002) The eastern Tonale fault zone: a'natural laboratory' for crystal plastic deformation of quartz over a temperature range from 250 to $700^{\circ} \mathrm{C}$. J Struct Geol 24:1861-1884. https://doi.org/10.1016/S0191-8141(02)00035-4

Takahashi N, Kodaira S, Nakanishi A, Park JO, Miura S, Tsuru T, Kaneda Y, Suyehizo K, Kinoshita H (2002) Seismic structure of western end of the Nankai trough seismogenic zone. J Geophys Res 107:ESE 2-1-ESE 2-19. https:// doi.org/10.1029/2000JB000121

Tester JW, Worley WG, Robinson BA, Grigsby CO, Feerer JL (1994) Correlating quartz dissolution kinetics in pure water from 25 to $625^{\circ} \mathrm{C}$. Geochim Cosmochim Acta 58:2407-2420. https://doi.org/10.1016/0016-7037(94) 90020-5

Toriumi M, Teruya J (1988) Tectono-metamorphism of the Shimanto belt. Mod Geol 12:303-324

Turcotte DL, Schubert G (2002) Geodynamics, 2nd edn. Cambridge University Press, Cambridge

Ujiie K, Yamaguchi A, Taguchi S (2008) Stretching of fluid inclusions in calcite as an indicator of frictional heating on faults. Geology 36:111-114. https://doi.org/10.1130/G24263A.1

Ujiie K, Saishu H, Fagereng Å, Nishiyama N, Otsubo M, Masuyama H, Kagi H (2018) An explanation of episodic tremor and slow slip constrained by crack-seal veins and viscous shear in subduction mélange. Geophys Res Lett 45:5371-5379. https://doi.org/10.1029/2018GL078374

Voss N, Dixon H, Liu Z, Malservisi R, Protti M, Schwartz S (2018) Do slow slip events trigger large and great megathrust earthquakes? Sci Adv 4:eaat8472. https://doi.org/10.1126/sciadv.aat8472

\section{Publisher's Note}

Springer Nature remains neutral with regard to jurisdictional claims in published maps and institutional affiliations.

\section{Submit your manuscript to a SpringerOpen ${ }^{\circ}$ journal and benefit from:}

- Convenient online submission

- Rigorous peer review

- Open access: articles freely available online

- High visibility within the field

- Retaining the copyright to your article

Submit your next manuscript at $\boldsymbol{\nabla}$ springeropen.com 